\title{
MAPPING SILESIAN IDENTITY IN CZECHIA
}

\begin{abstract}
T. Si wek, J. Ka ň ok: Mapping Silesian Identity in Czechia. - Geografie Sborník ČGS, 105, 2, pp. $190-200$ (2000). - The aim of the article is to investigate the degree of regional identity among inhabitants of the historical Czech land Silesia, to compare it with the available census data and to draw a cognitive map of Czech Silesia, that means mapping how Silesians themselves imagine their region. A general mental map of Silesia was drawn on the basis of individual respondents' maps. The map shows the core, domain and peripheral areas of the Czech Silesia in the minds of its inhabitants. This method was combined with interviews aimed at establishing respondents' sense of regional identity. The sense of Silesian identity is relatively strong among elderly people. It is quite weak among the young and - surprisingly - among the educated people. As every regionally based sentiment, Silesian identity is confronted with forces of globalisation now.

KEY WORDS: regional identity - perception - Silesia - Czechia.
\end{abstract}

\section{Introduction: the Silesian identity}

Contemporary Czechia consists of three historical lands. The two larger lands are fully integrated in the Czech state: Bohemia (52,052 square kilometres $=20,097$ square miles; $66.0 \%$ of the territory of the country) and Moravia $(22,231$ square kilometres $=8,583$ square miles; $28.2 \%$ of the territory). The third historical land is Silesia, a small part (only 4,423 square kilometres $=1,708$ square miles; $5.6 \%$ of the territory) of the historical province (appr. 40,000 square kilometeres $=15,400$ square miles). Most of the territory of Silesia belongs now to Poland.

Silesia as a whole is a typical border region, which was in turn under the Polish, Czech, Austrian and German supremacy. The dominant ethnic group from the Middle Ages were Germans. The western part of today's Czech Silesia was until 1945 populated mainly by Germans while its eastern part was dominated by ethnic Poles. The Czech ethnic population increased significantly after the incorporation of a substantial part of the former Austrian Silesia to Czechoslovakia in 1918. The main population change was connected with the expulsion of the German Silesians to Germany after World War II (that was $35 \%$ of the total population residing in the Czechoslovak Silesia before the war). New immigrants from the core areas of the Czech lands and Slovakia replaced the German population. The significant proportion of the present population of Czech Silesia are immigrants or immigrants' descendants. Original Silesians are a minority in Silesia not only due to the consequences of the war, but also as a result of the intensive development of heavy industry connected with massive immigration. The eastern part of Czech Silesia is the most industrialized area of the Czech Republic, full of coal mines, iron works and other branches of heavy industry. 
A specific historical destiny of Silesia contributed to a strong feeling of a special identity of its original inhabitants. This was not a complex identity of the national type, but only a territorial identity, which is a component of the higher-level national identity (Smith 1991). It was difficult to impose a clear national or ethnic classification on the indigenous Silesians whose identity was mostly territorial. In various censuses they were described as Germans, Poles or Czechs, contrary to their own identification as German Silesians, Polish Silesians and Czech Silesians or simply as Silesians. Their identity Silesianness - is not easy to define (see dificulties of defining the Germanness by Diana Forsythe, in Eriksen 1993). The Silesian territorial identity has never been supported by other identity components such as a common language and religion. A large number of Silesians speak their own dialects. The most specific Silesian dialect is typical of the Polish Silesians. Their dialect is basically Polish, but it is influenced by the Czech and partly by German language. Because Czech and German Silesians did not speak so specific "Silesian" dialects, Polish Silesians seem to be the most original component of Silesian population. For more details of Polish Silesians in the former Duchy of Teschen see Siwek 1992, 1995 and Hannan 1996. The Silesians were religiously divided into Roman Catholics and Lutheran Protestants from the sixteenth century in all three ethnic groups: German, Polish and Czech. The Silesian territorial identity of Silesian people has been based until now only on specific history and administrative status of this region.

\section{Administrative status of Silesia}

Silesia has never existed as an independent state. In the past it was divided into many small duchies under the reign of Polish Piast dynasty. In spite of feudal subdivisions Silesia existed as one province. From the fourteenth century it was a part of the Bohemian Kingdom. It became a part of the Austrian Habsburg Monarchy in 1526. Prussia gained almost the whole territory of the province in 1740. The Austrian Empire maintained control over a small part of Silesia as the Habsburg Crown Land named Austrian Silesia, which existed until 1918. The inhabitants of this province could still identify themselves as Silesians regardless of their language. The Austrian Silesia consisted of two different parts. The former Teschen Duchy was situated in the east, and it its dominant population was Polish. The former Opavia Duchy with fragments of counties of Krnov and Nisa was situated in the west and it was populated predominantly by Germans (for more details see Hannan 1996).

Newly established Czechoslovakia gained the Austrian Silesia and renamed it simply as Silesia (unofficial Czechoslovak Silesia) in 1918. Several years later, in 1927, the Czechoslovak government merged Silesia with Moravia and thus created the Moravian-Silesian Province. Historical borders of Silesia survived as district boundaries until 1949.

The communist government abolished provinces in Czechoslovakia in 1949. The old provinces were replaced by smaller territorial units: regions that were named after their capitals. Czech Silesia became a part of a newly established Region of Ostrava. The name of Silesia disappeared. Sub-units of those newly created regions, districts, were also changed and the old Moravian-Silesian boundaries disappeared as well. The new regions were enlarged in 1960 and 
the Czech Silesia became a part of a newly established North Moravia Region with its capital in Ostrava, the most industrialised Czechoslovak city. This situation remained unchanged until the collapse of the communist government in 1989.

The first post-communist democratic government abolished the regions in 1991 but the old districts stayed in place. A discussion of new administrative division of the country started immediately after the collapse of the communist regime. The idea of the reintroduction of former historical provinces was brought to the fore. It was supported mainly by Moravians. Behind these ideas and moves lurked the conviction that the central government's administrative capacity was inefficient. The aim of adherents of decentralisation was to delegate as much power as possible to the historical lands. The Movement for Autonomous Democracy - Society for Moravia and Silesia was established in 1990. It fought for the renewal of MoravianSilesian Province with a clear aim to reduce the power concentrated in Prague by winning as much of the state territory as possible including non-Moravian Silesia. The Moravians rejected some Silesian objections against the incorporation of Silesia into Moravia with arguments on the grounds that:

1. The territory of the region is too small, ten times smaller than Bohemia and five times smaller than Moravia. Still, because of a high density of Silesian population, the difference in terms of the size of the population is not as big in comparison with Moravia and Bohemia.

2. The original boundary between Silesia and Moravia used to be very complicated and now it has ceased to exist because of new regional structures of the industrialised area of Ostrava. Ostrava region of heavy industry has united former different historical lands. The area of the city of Ostrava is a good example of this process: its city centre is situated in the Moravian area surrounded by Silesian quarters in the west and east.

3 . The sense of identity of the Silesians is weak and the new population of Silesia - immigrants and young people - are not bearers of the Silesian identity at all.

\section{Silesia in the recent administrative units NUTS 3}

Slovak separatism resulting in the division of Czechoslovakia in 1993 strengthened arguments against the renewal of former large provinces. The Czech Republic without Slovakia would have consisted only of two provinces: Bohemia and Moravia-Silesia. Possible Bohemian-Moravian conflicts that could emerge in such a dual state could be very similar to the Czech-Slovak conflicts that led to the division of Czechoslovakia. A new administrative structure of the Czech Republic was therefore prepared with the aim of creating a large number of smaller units - regions. The idea to divide the state into three parts by restoring Silesia was left out of consideration for the reasons mentioned above.

In October 1997 the Czech Parliament passed the Act No 347/1997 about the new administrative division of the Czech Republic that came into effect on 1st January 2000. Now the area of the country is divided into 14 regions that correspond with the level NUTS 3 in the European Union. They are paradoxically very similar to the regions of the first communist administrative structure of Czechoslovakia between 1949 and 1960. By this act a substantial part $(85 \%)$ of Czech Silesia has become the part of the Region of Ostrava, 
except for the most western Silesian district of Jeseník, incorporated into the Region of Olomouc. The new Region of Ostrava now consists of 6 districts: the City of Ostrava, Bruntál, Karviná, Frýdek-Místek, Nový Jičín and Opava. $69 \%$ of its area is originally the historical Silesian territory and $31 \%$ of its area is on the territory of the historical land of Moravia.

Some reasons against the restoration of the historical Silesian Province such as its small area and unclear boundaries are rational and it is difficult to argue with them. Nevertheless, another very important reason against reestablishing the historical land of Silesia, a weak Silesian regional identity, demands a more rigorous scientific verification. Is the Silesian regional identity really so weak? Who are the bearers of this identity? Are the Silesians themselves really so little concerned with the restoration of their region? Last but not least, in what form does the Silesian region exist in minds of its inhabitants?

\section{The Silesians in the 1991 census}

The results of the last Czechoslovak census conducted in 1991 gave tentative answers to some of the above mentioned questions. For the first time this census allowed citizens to declare their Silesian identity as a nationality in the ethnic sense (the only exception in this respect was the 1939 census conducted by the German administration after the occupation of the region). The declaration of the Silesian nationality in 1991 was a consequence of political activities rather than traditions. It was a result of the campaigning of the Movement for Autonomous Democracy - Society for Moravia and Silesia, which was quite a powerful political force at that time (see Siwek 1992, 1995). However, unlike the inhabitants of the historical land of Moravia of whom almost 1.4 million declared themselves as ethnic Moravians, only by 44,000 people $(0.4 \%$ of the total Czech population and $5 \%$ of the population of the historical Silesian territory) chose the Silesian "nationality".

The census in 1991 showed the following demographic characteristics of citizens who declared themselves as Silesians (see tables $1-4$ ).

Statistical data confirm a general similarity between Silesians and the rest of the Czech population. However, there are three main differences: 1 . the number of the Silesian men is higher than the number of Silesian women; 2. the education of those who declared themselves as Silesians is a little lower than the average; 3 . more Silesian people are religious, most of them Roman Catholics, in comparison with the average share of the religious people in the Czech Republic.

\section{Results of the Silesian identity investigation in 1998}

The same statistical data characterise only a small group of Silesian population, considering themselves as a "nation". This group of population is undoubtedly the core of the whole population of the historic Silesian territory. Yet we need a better knowledge of the identity of the whole population of this area. In order to receive the representative data comparable with the census data we carried out a series of interviews with people who were selected as a representative sample of population living in the historic area of Czech 
Tab. 1 - Czech Silesians by age compared with total population of the Czech Republic by age

\begin{tabular}{|c|c|c|c|c|c|c|}
\hline \multicolumn{5}{|c|}{ The Silesians } & \multicolumn{2}{|c|}{ Total Czech population } \\
\hline Age & Men & Women & $\%$ of men & $\%$ of women & $\%$ of men & $\%$ of women \\
\hline $0-14$ & 4597 & 4429 & 10.33 & 9.97 & 10.76 & 10.25 \\
\hline $15-19$ & 2124 & 1767 & 4.78 & 3.98 & 4.32 & 4.13 \\
\hline $20-24$ & 1711 & 1282 & 3.85 & 2.88 & 3.40 & 3.25 \\
\hline $25-29$ & 1634 & 1449 & 3.68 & 3.26 & 3.41 & 3.27 \\
\hline $30-34$ & 1626 & 1349 & 3.66 & 3.04 & 3.35 & 3.25 \\
\hline $35-39$ & 1824 & 1700 & 4.17 & 3.82 & 3.94 & 3.88 \\
\hline $40-44$ & 2026 & 1721 & 4.56 & 3.87 & 4.11 & 4.08 \\
\hline $45-49$ & 1465 & 1277 & 3.30 & 2.87 & 3.29 & 3.35 \\
\hline $50-54$ & 1255 & 1126 & 2.83 & 2.53 & 2.49 & 2.62 \\
\hline $50-59$ & 1028 & 1103 & 2.31 & 2.48 & 2.37 & 2.64 \\
\hline $60-64$ & 1095 & 1276 & 2.46 & 2.87 & 2.34 & 2.85 \\
\hline $65-69$ & 1081 & 1326 & 2.43 & 2.98 & 2.05 & 2.85 \\
\hline $70-74$ & 527 & 659 & 1.19 & 1.48 & 1.02 & 1.56 \\
\hline $75-79$ & 391 & 695 & 0.88 & 1.56 & 0.95 & 1.70 \\
\hline $80+$ & 258 & 612 & 0.58 & 1.38 & 0.73 & 1.76 \\
\hline Unknown & 2 & 1 & 0.00 & 0.00 & 0.00 & 0.00 \\
\hline Total & 22674 & 21772 & 51.02 & 48.99 & 48.53 & 51.47 \\
\hline
\end{tabular}

Source: Czechoslovak census 1991

Tab. 2 - The Silesians over 15 years by education compared with the total population

\begin{tabular}{|c|c|c|c|c|c|c|c|c|c|}
\hline & \multicolumn{6}{|c|}{ The Silesians } & \multicolumn{3}{|c|}{ Total Czech population } \\
\hline & \multicolumn{2}{|c|}{ Total } & \multicolumn{2}{|c|}{ Men } & \multicolumn{2}{|c|}{ Women } & Total & Men & Women \\
\hline & abs. & $\%$ & abs. & $\%$ & abs. & $\%$ & $\%$ & $\%$ & $\%$ \\
\hline Primary & 11868 & 33.5 & 3967 & 21.9 & 7901 & 45.6 & 33.1 & 24.7 & 40.8 \\
\hline Lower secondary & 12780 & 36.0 & 8096 & 44.8 & 4664 & 26.9 & 35.4 & 39.3 & 28.2 \\
\hline Upper secondary & 8179 & 23.1 & 4263 & 23.6 & 3916 & 22.5 & 2.9 & 21.8 & 24.7 \\
\hline Tertiary & 2346 & 6.6 & 1626 & 9.0 & 720 & 4.2 & 7.2 & 10.7 & 5.1 \\
\hline Without education & 64 & 0.2 & 30 & 0.2 & 34 & 0.2 & 0.3 & 0.3 & 0.4 \\
\hline Unknown & 203 & 0.6 & 95 & 0.6 & 108 & 0.6 & 1.1 & 1.1 & 1.0 \\
\hline Total & 35420 & 100.0 & 18077 & 100.0 & 17343 & 100.0 & 100.0 & 99.9 & 100.2 \\
\hline
\end{tabular}

Source: Czechoslovak census 1991

Silesia. 920 inhabitants of the Czech Silesia were interviewed in November and December 1998. As the historic area of the Czech Silesia was considered the area of former Land of Silesia (administrative unit of the Austrian Habsburg Monarchy that integrated in Czechoslovakia after World War I including the district of Hlučín, until 1920 part of Germany). This area consists of 241 municipalities and it is populated by 938,000 inhabitants.

As a general rule, only people who were older than 15 years were interviewed. The respondents were selected by mixed, multilevel method. The first step was the selection of municipalities. Silesian municipalities were divided into categories according to the size of population. Individual municipalities were then selected by random sampling. The second step was sampling of respondents. They were selected by purposive quota sampling according to sex, age and the level of education. 
Tab. 3 - The Silesians by religious denomination compared with the total population

\begin{tabular}{|l|r|r|r|}
\hline Church & \multicolumn{2}{|c|}{ The Silesians } & $\begin{array}{c}\text { Total Czech } \\
\text { population }\end{array}$ \\
\hline & abs. & $\%$ & $\%$ \\
\hline Roman Catholic Church & 23976 & 53.9 & 39.1 \\
Silesian Evangelical Church & 1371 & 3.1 & 0.3 \\
Evangelical Church of Czech Brethren & 986 & 2.2 & 2.0 \\
Czechoslovak Hussite Church & 345 & 0.8 & 1.7 \\
Other Churches & 345 & 0.8 & 0.7 \\
Non-religious people & 11786 & 26.5 & 39.9 \\
Unknown & 637 & 12.7 & 16.1 \\
Total & 44446 & 100.0 & 100.0 \\
\hline
\end{tabular}

Source: Czechoslovak census 1991

Tab. 4 - The Silesians by economic activity

\begin{tabular}{|l|r|r|r|}
\hline \multirow{2}{*}{ Category } & \multicolumn{2}{|c|}{ The Silesians } & $\begin{array}{c}\text { Total Czech } \\
\text { population }\end{array}$ \\
\cline { 2 - 4 } & \multicolumn{1}{|c|}{ abs. } & $\%$ & $\%$ \\
\hline Economically active persons & 22658 & 51.0 & 52.6 \\
including: women on maternity leave & 1282 & 2.8 & 3.1 \\
working pensioners & 895 & 2.0 & 2.9 \\
job seekers & 512 & 1.2 & 1.2 \\
\hline Economically inactive persons & & & \\
with their own income & 9091 & 20.5 & 19.3 \\
\hline Dependants, including: & 12697 & 28.6 & 28.1 \\
\hline apprentices & 1327 & 3.0 & 2.9 \\
children, pupils, students & 10604 & 23.9 & 24.2 \\
housewives & 758 & 1.7 & 0.8 \\
\hline Total & 44446 & 100.0 & 100.0 \\
\hline
\end{tabular}

Source: Czechoslovak census 1991

There are two major results of this investigation: statistical characteristics of the residents in the historic territory of Silesia and the cognitive map of their own region. For the theoretical aspects of mental maps see Gould, White 1974; in the Czech geographical literature see Drbohlav 1991. The mental map of the Czech Silesia does not show the environmental perception as maps of preference (Drbohlav, Blažek 1990, Bartnicka 1989), but as a map of respondents' image of their region (Drbohlav 1991).

Apart from inviting the respondents to draw a map of Silesia the respondents were also asked about the character of their connection with the territory of historic Silesia and about their identity in terms of their nationality (their identity was compared with their identity declared during the census in 1991). They were also asked about their attitude to the supposed form, name and capital of the new administrative unit which would contain most of the territory of the Czech Silesia. They were also asked if they thought that their own town was on the territory of Silesia. Finally, they were asked to draw the map of Silesia. 
Tab. 5 - The sample: 920 people, 441 men and 479 women. Origin of the respondents and their parents.

\begin{tabular}{|l|c|c|c|}
\hline & Respondents & $\begin{array}{c}\text { Respondents' } \\
\text { fathers }\end{array}$ & $\begin{array}{c}\text { Respondents' } \\
\text { mothers }\end{array}$ \\
\hline born in Silesia & $76.7 \%$ & $58.3 \%$ & $61.2 \%$ \\
born in Moravia & $17.1 \%$ & $23.6 \%$ & $23.0 \%$ \\
born in Bohemia & $2.5 \%$ & $4.4 \%$ & $3.7 \%$ \\
born in Slovakia & & $7.4 \%$ & $6.5 \%$ \\
born in other countries & $3.7 \%$ & $3.2 \%$ & $3.0 \%$ \\
living in other places & & $3.3 \%$ & $2.5 \%$ \\
\hline
\end{tabular}

Source: authors' research

Tab. 6 - Respondents' nationality (in \%) in 1991 and 1998

\begin{tabular}{|l|r|r|}
\hline & 1991 & 1998 \\
\hline Czech & 82.7 & 77.9 \\
Moravian & 5.0 & 8.6 \\
Silesian & 3.6 & 5.8 \\
Polish & 3.4 & 3.0 \\
Slovak & 2.5 & 2.2 \\
German & 0.3 & 1.0 \\
Others & 0.4 & 1.2 \\
No answer & 2.1 & 0.4 \\
\hline
\end{tabular}

Source: authors' research

Tab. 8 - Proposed name of a new administrative unit - Region of Ostrava

\begin{tabular}{|l|r|}
\hline Combine Moravia and Silesia & 34.2 \\
\hline including: Moravian-Silesian & 23.8 \\
North Moravian - Silesian & 5.9 \\
Silesian-Moravian & 6.0 \\
\hline Only Silesian & 9.0 \\
\hline Only North Moravian & 27.9 \\
\hline Other & 0.9 \\
\hline No answer & 26.5 \\
\hline
\end{tabular}

Source: authors' research
Tab. 7 - The attitude to administrative units prepared in 1998. Respondents were informed of the introduced administrative structure $(\%)$

\begin{tabular}{|l|r|}
\hline well & 8.0 \\
partly & 33.7 \\
not at all & 50.3 \\
no answer & 8.0 \\
\hline
\end{tabular}

Source: authors' research

Tab. 9

\begin{tabular}{|l|c|c|}
\hline \multirow{2}{*}{ Answer } & \multicolumn{2}{|c|}{ Respondents from } \\
\cline { 2 - 3 } & $\begin{array}{c}\text { Teschen } \\
\text { part of } \\
\text { Silesia }\end{array}$ & $\begin{array}{c}\text { Opavian } \\
\text { part of } \\
\text { Silesia }\end{array}$ \\
\hline $\begin{array}{l}\text { My town is } \\
\text { situated } \\
\text { in Silesia }\end{array}$ & 86.9 & 75.2 \\
I do not know & 3.9 & 7.9 \\
$\begin{array}{l}\text { My town is not } \\
\text { situated in } \\
\text { Silesia }\end{array}$ & 9.2 & 16.9 \\
\hline
\end{tabular}

Source: authors' research

Most Silesians who took part in this research had strong bonds with the territory of Silesia. $76.7 \%$ of respondents were born in Czech Silesia and at least $58.3 \%$ of respondents' parents were born in Czech Silesia as well. A clear majority of respondents can be considered as long-term inhabitants. It appears that the tremendous consequences of a mass migration after the World War II are now overcome (Tab. 6).

The share of common Central European nationalities in our survey is similar to the census in 1991. Nevertheless, our data differ from that census 
in two significant ways. Both regional identities considered by respondents as "nationalities" - Moravian and Silesian - are increasing (Tab. 7).

It seems that people were not very well informed about the new administrative structure. The structure of respondents suggesting the name for their new administrative region is interesting. It must be explained that the new Region of Ostrava contains almost $70 \%$ of the territory of Czech Silesia (Tab. 8).

This table shows that the Silesian identity is rather weak. It is a consequence of the long-term marginalisation of the name of Silesia during the communist period. The number of respondents preferring a geographically incorrect name North Moravian Region was three times higher than the number of respondents preferring the name of Silesia, which is geographically incorrect, too. Geographically correct names combining words Moravian and Silesian were preferred by one third of respondents, but the majority of them put the name Moravian (or North Moravian) in the first place. Approximately one fourth of respondents did not answer this question - it is an evidence of their lack of interest.

One of the main questions of our questionnaire was aimed at the identification of respondents' place of living: whether or not it was situated in their view on the historical territory of Silesia. Former Austrian or Czechoslovak Silesia that was determined by district boundaries valid at least from 1850 (first Austrian district structure) to 1949 (when historical lands were abolished by communists) was considered as the historical Silesia. All respondents were residents of this historical area of Czech Silesia. 81.4\% of them considered their own town as a part of historical Silesia. $12.8 \%$ of the respondents did not consider their own town as a part of Silesia and $5.8 \%$ of the respondents did not answer this question.

We tried to analyse the structure of the respondents. Their age was not found to be important. Only $78.2 \%$ of the youngest respondents classified their own town as a Silesian town, contrary to $90.8 \%$ of the respondents between $60-64$ years. Surprisingly, only $83.6 \%$ of the oldest respondents called their place of living as Silesian. Respondents' education was not significant either. Only $76.1 \%$ of the most educated people with a university degree situated their own town in the territory of Silesia, fewer than the other, less educated respondents who did it in $81-83 \%$ of cases. It means that for educated people the question of localisation of their town is not so important. Job situation is not significant in this case either: surprisingly, the unemployed people's identification of their place of living as Silesian was highest $(85,9 \%)$. The scores for university students and university graduates were lowest $(73,2 \%$ and $73,9 \%)$.

The respondents' territorial origin was more important. The best results were achieved by people born in Silesia as well as by respondents with Silesian parents and, strangely enough, by respondents born in relatively distant Bohemia as well as by respondents whose parents came from Bohemia. The worst results were related to Moravians and to the respondents who had Moravian and Slovak parents. It means that Moravians either do not differentiate Silesia from Moravia or that they consider Silesia as a Moravian sub-region. The relatively correct localisation of Silesia by the Czechs coming from Bohemia could be a result of their subconscious tendency to limit the influence of their possible rivals - the Moravians.

Inner Silesian regions are significant as well. The Teschen Silesians localised better their area than the Opava Silesians. It is an evidence, that population of Teschen Silesia is more original in this area than Opavian 
population in their region. It is evident that the Opavian Silesia is still affected by forced migration after the World War II. See table 9.

This table is significantly different from the results of the 1991 census, because the census shows the stronger Silesian identity of the inhabitants of Opavian Silesia. This phenomenon may be explained by the fact that most Poles living in Teschen Silesia can be regarded as a people with a strong Silesian identity (Siwek 1997).

\section{The mental map of Czech Silesia}

The last part of our research was to establish how respondents imagined the map of the Czech Silesia. Each respondent was asked to draw his or her own map of the Silesian region. On the basis of individual respondents' maps the general mental map was drawn. Each municipality in the Czech Silesia and surroundings was classified according to the frequency with which it appeared as a part of Silesia in individual respondents' maps. The municipalities were then divided into intervals according the theory of scales (Kaňok 1999a). The final map was drawn by the programmes ARC/INFO and ArcView. The mental map of Silesia is presented below (see Fig. 1).

In the respondents' views the core of Silesian region consists primarily of the districts of Opava and Karviná and partly also the city of Ostrava and the district of Frýdek-Místek. The district of Bruntál, a part of the district of Nový Jičín and quite a peripheral district of Jeseník were only exceptionally considered to be part of Silesia. The map shows both the core and peripheral areas of the Czech Silesia as they are perceived by its inhabitants.

The analysis of the respondents' sample did not reveal any significant differences. The older respondents drew a Silesian area with a slightly higher precision than the younger ones. The educated respondents did not draw a Silesian area better than uneducated people. Similarly, neither respondents' job nor gender was significant in determining the accuracy of their maps. Territorial origin of respondents could be more important. The results of our research showed also that there was no significant distinction in the ability of the respondents from Teschen and Opavian part of Silesia to draw a map of Silesia. However, to determine the types of errors that these respondents made when drawing the map was left out from our analysis.

\section{Conclusions}

The Czech Silesia exists in its inhabitants' minds only to a limited extent. Historic Silesia is not usually associated by the inhabitants of Silesia with a newly established administrative structure of the Czech Republic. Restoration of Silesia is not a pressing problem for the majority of its population. This problem is significant only for the minority of old residents for those who declared themselves as Silesians in the west and for the Poles in the east of the region. The growth of the tendency to declare Silesian identity as "nationality" (as well as Moravian "nationality") is interesting but seems to be a consequence of political processes rather than of the growth of the regional identity. The adherents to Silesian identity are predominantly elderly people. The educated people and students from the region consider the problem of the restoration of historical Silesia as marginal. The change of 


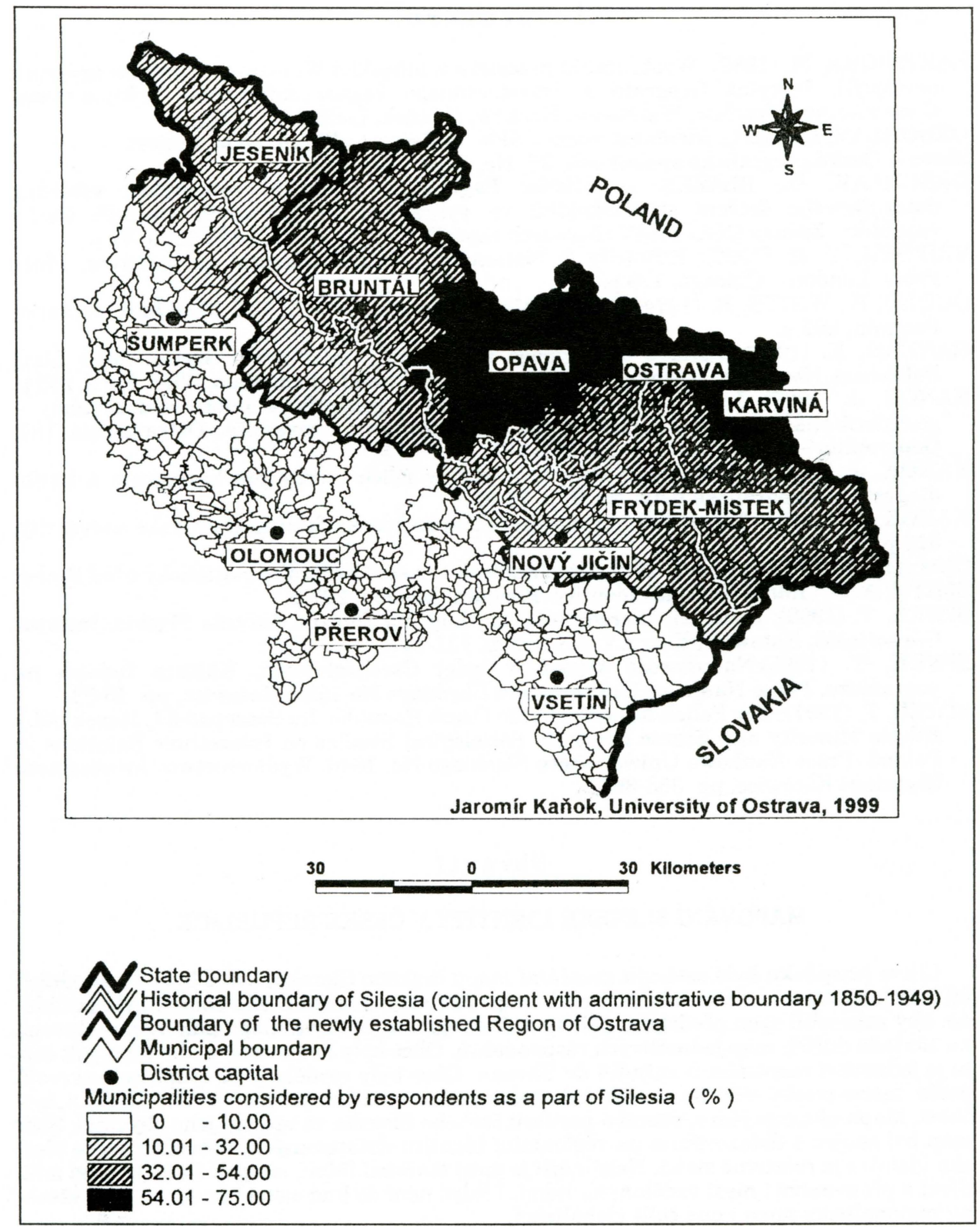

Fig. 1 - The mental map of Silesia in the area of former North Moravian Region.

social and cultural climate in Czechia after the fall of communism could increase the interest of the Silesians in their own region but at present the prospect of the strengthening of the Silesian identity is quite grim. It is not without any chance in the future but it is exposed to the forces of globalization as all other regional identities in the world. 


\section{Literature:}

BARTNICKA, M. (1989): Wyobrażenia przestrzeni miejskiej Warszawy (Studium geografii percepcji). Instytut Geografii i Przestrzennego Zagospodarowania. Dokumentacja Geograficzna, Wrocław, Warszawa, Kraków, Gdańsk, Łódź, No. 2, 92 p.

DRBOHLAV, D. (1991): Mentální mapa ČSFR. Definice, aplikace, podmíněnost.

Sborník České geografické společnosti, 96, No. 3, pp. 163-176.

DRBOHLAV, D., BLAŽEK, J. (1990): Regionální a sídelní preference; výsledky dotazníkového šetření středoškoláků ve vybraných 11 okresních městech České republiky. Zprávy GGÚ ČSAV (Research report). Praha, GGÚ ČSAV, 1990, 91 p.

ERIKSEN, T. H. (1993): Ethnicity \& Nationalism. Anthropological perspectives. Pluto Press, London - Chicago, 179 p.

GOULD, P., WHITE, R. (1974): Mental Maps. Harmondsworth, UK, Markham, Ontario: Penguin, $203 \mathrm{p}$.

HANNAN, K. (1996): Borders of language and identity in Teschen Silesia. Peter Lang Publishers, New York, Washingon, Baltimore, Bern, Frankfurt am Main, Wien, Paris, 255 p.

KAŇOK, J. (1997): Informační systémy o území - geografické informační systémy geoinformatika. In: Acta Facultatis Rerum Naturalium Universitas Ostraviensis, 167, Geographia - Geologia, No. 5, pp. 121-142.

KAŇOK, J. (1999a): Klasifikace stupnic a zásady jejich tvorby pro kartogram a kartodiagram. Kartografické listy, No. 7, p. 75-86.

KANOK, J. (1999b): Tematická kartografie. Přírodovědecká fakulta Ostravské univerzity, $318 \mathrm{p}$.

Sčítání lidu domů a bytů 3. 3. 1991 (Czechoslovak Census) Federální statistický úřad Praha.

SMITH, A. D. (1991): National Identity. Penguin, London, 227 p.

SIWEK, T. (1992): Fenomen "narodowości śląskiej” na Zaolziu. Zaranie Śląskie, Instytut Górnośląski, Katowice, Year LV, No. 1-2, p. 131-141.

SIWEK, T. (1995):Narodowość śląska w byłej Czechosłowacji. Kultura ludowa na pograniczu. Prace Naukowe Uniwersytetu Śląskiego No 1520, Katowice, pp. 46-53.

SIWEK, T. (1997): The Polish Minority in the Czech Republic. In: Szczepański, Marek (ed.): Ethnic Minority and Ethnic Majority. Sociological Studies on Interethnic Relations in Poland. Prace Naukowe Uniwersytetu Śląskiego No. 1646. Wydawnictwo Uniwersytetu Śląskiego Katowice, pp. 353-365.

\section{Shrnutí}

\section{MAPOVÁNÍ SLEZSKÉ IDENTITY V ČESKÉ REPUBLICE}

Cílem příspěvku bylo sestrojit mentální mapu českého Slezska, které bylo v posledních 50 letech vymazáno $\mathrm{z}$ administrativních map. 920 respondentủ z této oblasti bylo požádáno, aby zakreslili svou představu polohy svého regionu. Celková mapa pak byla sestavena na základě dílčích map jednotlivých respondentů. Obce byly hodnoceny podle toho, jak často je jednotliví respondenti zařadili do Slezska. Obce byly rozděleny do stupnice intervalů podle teorie tvorby stupnic a mapa byla sestrojena s využitím programů ARC/INFO a ArcView. Mapa ukazuje jádro, území a periferii českého Slezska ve vědomí jeho obyvatel. Sběr map byl spojen s dotazováním na regionlální identitu dotazovaných. Potvrdilo se, že slezská identita je relativně slabá. Nejsilnější je mezi staršími lidmi, naopak slabá je mezi mladými a překvapivě i mezi vzdělanými lidmi. I když není do budoucna bez šancí, jako všechny regionalismy musí i ona čelit globalizaci.

Obr. 1 - Mentální mapa Slezska v bývalém Severomoravském kraji. 1 - Státní hranice, 2 - historická hranice Slezska (administrativní hranice z let 1850 - 1949), 3 - hranice nově vytvořeného Ostravského kraje, 4 - hranice obcí, 5 - okresní město, 6 - obce, které respondenti považují za součást Slezska (podíl v \%).

(T. Siwek is with Ústav pro výzkum polského etnika Philosophic Faculty of Ostrava University, Dvořákova 7, 70103 Ostrava, Czechia. J. Kaňok is with Department of Geography, Faculty of Science, Masaryk University, Kotlářská 2, 61137 Brno, Czechia.) 